С. О. Смолова

канд. пед. наук, доцент

\title{
ФОРМУВАННЯ ОРФОГРАФІЧНИХ УМІНЬ І НАВИЧОК УЧНІВ ЗАСОБОМ ВИКОРИСТАННЯ АКТИВНИХ МЕТОДІВ НАВЧАННЯ В ПРОЦЕСІ ВИВЧЕННЯ НІМЕЦЬКОЇ МОВИ
}

У статті розглянуто проблему формування орфографічних умінь і навичок учнів у прочесі вивчення німецької мови.

Модернізація сучасної шкільної системи освіти передбачає активне вивчення учнями іноземних мов. Одним із найважливіших завдань вивчення німецької мови в сучасній школі $є$ формування орфографічних умінь і навичок. Учні повинні навчитися знаходити в словах орфограми, правильно писати слова з вивченими орфограмами, знаходити і виправляти орфографічні помилки. Основна мета навчання техніки письма в школі полягає у формуванні в учнів каліграфічних та орфографічних навичок.

$$
-160-
$$


Під каліграфічними навичками розуміють навички написання усіх букв та буквосполучень певної (в нашому випадку - німецької) мови, що найчастіше формуються на початковому етапі ії вивчення.

Орфографічні навички - це автоматизовані компоненти свідомої діяльності, які передбачають знання учнями орфографічних правил, уміння виявляти визначальні ознаки орфограм та здійснювати орфографічний розбір і відповідні орфографічні дії, що виробляються в процесі виконання цієї діяльності, безпосередній наслідок засвоєння орфографічних знань, які зміцнюються в процесі повторного застосування їх на практиці під час розв'язання орфографічних завдань при виконанні вправ. Тому-то важливими умовами оволодіння орфографічними навичками $\epsilon: 1)$ глибоке, усвідомлене засвоєння учнями теоретичних положень орфографії; 2) уміння застосовувати їх у практиці письма; 3) достатня кількість орфографічних вправ.

Серед важливих умов оволодіння орфографічними навичками виділяють такі: глибоке, свідоме засвоєння учнями теоретичних положень орфографії, застосування цих положень на практиці, виконання достатньої кількості орфографічних вправ. Важливе практичне значення має розкриття усталених між мовними явищами взаємозв'язків, зокрема орфографії $\mathrm{i}$ граматики. Граматика становить основу орфографії.

Вивчення правопису німецької мови на граматичній основі обгрунтовують I. Л. Бим, К. О. Ганшина, I. М. Горелов, О.О.Миролюбов, Р. П. Недеялков, Е.І. Пассов, О.І. Томсон та інші методисти.

Орфографічна система німецької мови грунтується на трьох основних принципах: фонетичному, коли буква повністю відповідає звуку; морфологічному, коли написання визначається правилами граматики, незалежно від фонетичних відхилень у вимові однієї і тієї ж букви; історичному, або традиційному. Провідними принципами в орфографії німецької мови $є$ фонетичний та морфологічний принципи, тому їм необхідно приділяти більше уваги під час формування орфографічних навичок школярів.

Механізм формування в учнів орфографічних умінь і навичок довготривалий. «Це пов'язано з особливостями пам'яті, для якої характерні не лише властивості запам'ятовування і відтворення, а й забування. Тому методика оволодіння орфографією передбачає періодичну корекцію учнівської вправності на основі системи послідовно виконуваних дій. Сюди входить: 1) спостереження й аналіз діалектичної чи видозмінної дією спорідненої мови лексеми з неправильно вжитою орфограмою; 2) зіставлення іiї 3 нормативним написанням літературної мови; 3) виконання аналітичних вправ для запобігання правописних відхилень, орфографічного розбору тощо; 4) конструювання слів за поданими моделями і без них, утворення граматичних форм; 5) творчі вправи, що включають у себе складання зв'язних текстів, вправи - редагування, переклади; 6) диктанти» $[7,167]$. 
У «Пояснювальній записці» чинної програми для загальноосвітніх навчальних закладів «Німецька мова. 5-11 класи» визначаються основна мета і завдання, освітні функції німецької мови. Зокрема, основна мета ії вивчення в загальноосвітніх навчальних закладах України на сучасному етапі полягає у формуванні духовно багатої мовної особистості, яка володіє вміннями й навичками вільно, вміє комунікативно виправдано користуватися засобами мови - iї стилями, типами, жанрами в усіх видах мовленнєвої діяльності (аудіювання, читання, говоріння, письмо).

Відповідно до поставленої мети головними завданнями навчання німецької мови є:

- вироблення в школярів умінь і навичок комунікативно виправдано користуватися засобами мови в різних життєвих ситуаціях під час сприймання, відтворення і створення висловлювань 3 дотриманням німецького мовленнєвого етикету;

- засвоєння учнями базових орфоепічних, граматичних, лексичних, правописних, стилістичних умінь і навичок;

- ознайомлення учнів з мовною системою як основою для формування мовних, мовленнєвих умінь і навичок.

Аби забезпечити розв'язання поставленої мети і завдань, що з неї випливають, а також щоб надати шкільному курсу німецької мови практичної спрямованості, зміст програми диференційовано на чотири взаємопов'язані змістові лінії: лінгвістичну, комунікативну, культурологічну і діяльнісну.

Всі чотири змістові лінії тією чи іншою мірою відіграють важливу роль у формуванні орфографічних вмінь і навичок школярів. Лінгвістична змістова лінія включає в себе основні мовознавчі поняття, вимоги до роботи над орфоепічними і граматичними нормами німецької мови, правилами з орфографії та пунктуації.

Важливе пізнавально-практичне значення комунікативної лінії полягає в розкритті існуючих між мовними явищами різних рівнів взаємозв'язків (словотвору і морфології, морфології і синтаксису, орфографії і фонетики, орфографії і морфологіï).

Оволодіння учнями граматичними засобами мови відбувається за допомогою спеціальних вправ, які дають можливість використовувати вивчені мовні категорії і конструкції, сприяють виробленню орфографічних навичок.

Діяльнісна змістова лінія забезпечує цілеспрямоване формування досвіду творчої діяльності і підвищення рівня грамотності учнів. Не менш важливу роль у навчальній діяльності відіграють комунікативна і культурологічна змістові лінії.

Проаналізувавши змістові лінії, ми побачили, що одним із основних завдань курсу німецької мови в школі $\epsilon$ вироблення в учнів міцних орфографічних навичок. У процесі вироблення орфографічних навичок учень по-

$$
-162-
$$


винен не тільки вибрати відповідне орфограмі правило, але й виконати весь комплекс дій, закладених у його змісті.

Навичка - це автоматизовані компоненти свідомої діяльності, що виробляються в процесі ii виконання. Навички формуються на базі умінь (П. Я. Гальперин, Д. Б. Ельконін, О. М. Кабанова-Меллер та інші). Уміння в свою чергу пов'язані із засвоєнням знань та їх використанням під час письма. Успішне формування орфографічних навичок можливе за умови високого наукового рівня викладання орфографії; зв'язку між формуванням орфографічних навичок та розвитком мови; знання схеми застосування правил та вміння здійснювати орфографічний розбір, що забезпечує використання правил; упровадження вправ, спрямованих на відпрацювання умінь використовувати орфографічні правила. Теоретичну (лінгвістичну) основу орфографічних дій складають знання з фонетики, словотворення, морфології, синтаксису.

Теоретичну основу орфографічних дій складають спеціальні знання 3 орфографії, що стосуються позначення звуків буквами, роздільного написання, написання слів разом та дефісного написання; використання прописних літер; переносу сліз з одного рядка на інший.

«Орфограма - це написання, що регулюється певним правилом або визначається за словником» $[2,8]$. Уміння виявити (визначити) орфограму формується під час використання всіх орфографічних правил. Таке уміння називають орфографічною пильністю.

Теоретичну основу вивчення орфограм складають їх визначальні ознаки. Під час вивчення орфографічного правила вчитель повідомляє учням визначальні ознаки орфограми і вимагає їхнього запам'ятовування.

Вправи, що сприяють розвитку орфографічної пильності, тобто тому, що школярі вчаться знаходити орфограми за їх визначальними ознаками:

- знайти в тексті вивчені орфограми (усно або письмово);

- записати тексти та підкреслити вивчені орфограми;

- підібрати слова з тією ж орфограмою, яка є в наведеному прикладі;

- згрупувати орфограми (усно або письмово).

Під час виконання вправ орфографічного характеру вчитель повинен вимагати від учнів вказування ними визначальних ознак відповідної орфограми, а також запам'ятовування формулювань орфографічних правил.

Відомо, що орфографічна навичка $є$ необхідним компонентом письмової мови, тобто орфографічна навичка - мовна навичка. Ось чому заняття 3 орфографії пов'язують із роботою з розвитку мови учнів. Розвивати мову учнів -означає працювати над вимовою, значенням морфем, слів та фразеологізмів, над морфологічною формою слів, над словосполученнями, реченнями, зв'язною (контекстною) мовою. Чинна програма 3 німецької мови передбачає роботу з розвитку мови в трьох напрямках:

1) оволодіння нормами німецької літературної мови;

2) збагачення словникового запасу та граматичної будови мови учнів; 
3) формування умінь та навичок зв'язного викладу думок в усній та письмовій формах.

Формування орфографічних навичок є свідомим процесом і передбачає наступні етапи:

1) формування в учнів орфографічних правил;

2) формування вміння виявляти визначальні ознаки орфограм та здійснювати орфографічний розбір;

3) формування вміння здійснювати орфографічні дії.

Метод навчання - взаємопов'язана діяльність викладача та учнів, спрямована на засвоєння учнями системи знань, набуття умінь і навичок, ïx виховання і загальний розвиток. У вузькому значенні метод навчання $\epsilon$ способом керівництва пізнавальною діяльністю учнів, який має виконувати три функції: навчаючу, виховну і розвиваючу. Інколи «метод» визначають як спосіб упорядкованої взаємопов'язаної діяльності вчителя і учнів, спрямований на досягнення певної мети. У практиці традиційної школи списування тексту та диктанти були одним із засобів формування культури писемного мовлення учнів, вони виконували організуючу і виховну роль допомагали сформувати цінні навички регламентованої роботи, уміння дотримуватися встановленого порядку і ритму. У практиці роботи сучасної школи засобом формування культури писемного мовлення школярів $є$ активні методи навчання.

Г. Ващенко, С. Голант «активними методами навчання» називають ті методи, які максимально підвищують рівень пізнавальної активності учнів, спонукають їх до старанності в навчанні, міцного засвоєння знань. Г. Ващенко вважає, що поділ методів на пасивні та активні передбачає ситуацію, коли в умовах використання пасивних методів активна роль належить учителю, а учень лише засвоює матеріал. Протилежна ситуація передбачає, що активна роль у здобутті знань належить учню, а вчитель лише допомагає йому, створюючи сприятливі умови.

За класифікацію Є. Голанта, що склалася в 60-ті роки, «методи поділяються на пасивні (усний виклад навчального матеріалу вчителя, розповідь, пояснення, інструктаж, демонстрація тощо), коли домінуючою є активність самого вчителя, недостатня пізнавальна активність учнів, та активні методи навчання, які передбачають самостійну роботу учнів, їх активну пізнавальну діяльність, до них належать такі як бесіда, дискусія, дебати i суди, дидактична гра, дуель за схемою «запитання - відповідь», рольова гра, робота з підручником, спостереження» $[5,4]$.

Педагогічною психологією виведений основний закон засвоєння: сприйняти - осмислити - запам'ятати - використовувати - перевірити результат. Усі етапи засвоєння недоцільно розривати, оскільки вони взаємопов'язані. Тому саме використання активних методів навчання сприяє інтенсивній роботі учнів на уроці: уважно слухаючи, вони думають; споглядаючи - думають, читаючи - думають і виконують практичні завдання, думаючи. 
Так, завдання-діалоги мають великі можливості мотиваційноспонукального характеру, що дозволяє створювати атмосферу спілкування, у якій виникають мотиви для висловлювань. Тому ми уникали завдань типу: «Опишіть...», «Перекажіть...», «Назвіть...», «Перерахуйте...». Натомість ми пропонували школярам дати відповіді на запитання: «Що ви думаєте про...?», «Як ви вважаєте...?», «Чи згодні ви, що...?», «Яка ваша думка...?», уважаючи їх набагато продуктивнішими.

У процесі обговорення виникає природна мовна комунікація, що знаходить свій подальший розвиток за наявності в співрозмовників різних гіпотез. Обговорення різних точок зору на проблему, що розглядається, $\epsilon$ природним стимулом, який спонукає учнів до дискусії. При цьому вони вчаться обгрунтовувати правильність своїх відповідей, відхиляти помилкові судження, згоджуватися чи не згоджуватися з доказами інших. Практика доводить доцільність застосування таких ситуацій на уроках німецької мови. Розглянемо, як це нами здійснювалося.

Так, під час вивчення лексичної теми «Їжа. Кафе» учням пропонувалося таке завдання: скласти кілька ситуацій (діалогів), спираючись на приклад.

Hang und Peter gehen ins Gasthaus. Sie rufen den Ober.

Peter: Herr Ober, ich mцchte die Speisekarte, Bitte!

Ober: Hier, meine Herren!

Peter: Danke!

Ober: Mцchten Sie das Menu zu 15,60? Das ist heute sehr gut.

Peter: Was gibt's denn? Hm, Gemsesuppe, Rindfleisch mit Kartoffeln und Salat, und einen Nachtisch. Ja, Bringen Sie mir das, und ich mцchte noch ein Bier Bitte!

Hans: Danke. Ich nehme auch dieses Menь, aber darf man ohne Suppe?

Ober: Natbrlich. Man darf. Und was trinken Sie?

Hans: Jetzt noch nichts; aber nach dem Essen mцchte ich eine Tasse Kaffe.

Peter: Darf man fragen, dauert es lange?

Ober: Aber nein, ich bringe die Suppe sofort.

Для більш повної реалізації можливостей іноземної мови в розвитку навичок міжособистої взаємодії учнів у спілкуванні методику нашої дослідної роботи ми будували таким чином, щоб у спілкуванні могли брати участь всі школярі. Результати дослідного навчання показали, що учні успішно засвоїли мовні функції повідомлення, коментування, контраргументування, доповнення, припущення. Діалогічне спілкування допомогло сформувати також такі важливі риси, як повага до співрозмовника, щирість, прагнення до взаєморозуміння. Під час навчання учні оволодівали технікою спілкування, мовним етикетом, стратегією і тактикою діалогічного та групового спілкування, училися вирішувати комунікативні завдання, бути мовними партнерами.

У процесі діалогічного навчання в учнів формується культура спілкування, ініціативність, цілеспрямованість. Діалогічне навчання

$$
-165-
$$


сприяє формуванню в школярів здатності створювати мовленнєві ситуації, досягати рівності в стосунках під час комунікації, розвиває мовлення, емоційну сферу, здатність до емпатії, комунікативної взаємодії.

Активні методи - це такі методи навчання, які формують в учнів потребу в нових знаннях; спрямовують навчання на зв'язок із життям; спрямовують мислення на вирішення загальних і часткових пізнавальних завдань $з$ метою творчої переробки навчальної інформації; забезпечують діяльність, спрямовану на співвідношення часткових відомостей з основними ідеями; сприяють озброєнню учнів міцними знаннями і навичками, а також умінням переносити їх в нові умови; сприяють оволодінню навчальними уміннями; створюють максимальні умови для активної навчальнопізнавальної діяльності кожного учня.

Процес навчання розглядається в сучасній педагогічній науці як активна пізнавальна діяльність учнів, у результаті якої вони під керівництвом учителя оволодівають знаннями, уміннями та навичками, розвивають творчі сили та здібності, унаслідок чого формується їх науковий світогляд. Разом з тим це цілеспрямований, організований процес взаємодії, співпраці та співтворчості вчителя і учнів.

Головним у процесі навчання $є$ переорієнтація 3 пасивних форм навчання на активну творчу працю як учнів, так і вчителів. У навчальному процесі слід об'єднати творчу активність учителя і учнів так, щоб учні психологічно відчували себе творцями цього навчального процесу, учасниками спільного творчого пошуку.

Активними методами навчання $є$ також: аналіз конкретних ситуацій, «інтелектуальна розминка», «мозкова атака», навчальна тематична дискусія, дидактичні ігри, рольові ігри, тренінги, проведення різноманітних нестандартних уроків, творчі проекти.

Нами були визначено та експериментально перевірено педагогічні умови ефективного формування орфографічних умінь і навичок учнів засобом використання активних методів навчання на уроках німецької мови, а саме: володіння вчителем німецької мови методикою викладання орфографії; варіативність вибору активних методів навчання німецької мови i їх поєднання; різноманіття навчальних завдань на уроках німецької мови; створення в навчальному процесі ситуації успіху для кожного учня.

Таким чином, використання активних методів навчання в процесі вивчення німецької мови дозволило змінити позицію учнів зі звичайних слухачів, які пасивно отримують знання, на активних учасників навчального процесу. Саме дотримання означених вище педагогічних умов забезпечує ефективне формування орфографічних умінь і навичок учнів на уроках німецької мови. У свою чергу активні методи навчання сприяють формуванню позитивного ставлення учнів до вивчення німецької мови. Проведене дослідження дає підстави стверджувати, що слід дбати, по-перше, про поетапне формування орфографічних знань, умінь і навичок учнів, що в основ- 
ній школі забезпечується системою вправ; по-друге, про необхідність урахування, з одного боку, психологічних закономірностей формування навичок у школярів різних вікових груп, з іншого - лінгвістичної природи орфограм; по-трете, про доцільне використання активних методів навчання в процесі формування орфографічних умінь та навичок учнів старших класів.

\section{Список використаної літератури}

1. Алгазина Н. Н. Предупреждение орфографических ошибок учащихся 59 классов. - М.: Просвещение, 1965. - 280 с.

2. Алгазина Н. Н. Формирование орфографических навыков. - М.: Просвещение, 1987. $-160 \mathrm{c}$.

3. Бернацький М.I. Методика орфографії в середній школі. - К.: Рад. школа, 1940. - 189 с.

4. Богоявленский Д. Н. Психология усвоения орфографии. - М.: Просвещение, 1966. - $116 \mathrm{c}$.

5. Голант Е. Я. Методы обучения в современной школе. - М, 1977. -205 с.

6. Методика викладання іноземних мов у середніх навчальних закладах: Підручник. Вид. 2-е випр. і перероб. / Коло авторів під керівн. С. Ю. Ніколаєвої. - К.: Ленвіт, 2002. -328 с.

7. Теоретические основы методики обучения иностранным языкам в средней школе / Под ред. А. А. Миролюбова. - М.: Просвещение, 1981. - 217 с.

\section{Summary}

The article deals with the problem of formation spelling skills and abilities of students in the process of studding of German. 